\title{
オンボード計測による火花点火燃焼の解釈
}

\section{On-Board Measurements for better understanding of Combustion in A Spark Ignition Engine}

\section{伊東 輝行 （日産自動車）角方 章彦（日産自動車） 橋䓀 豊（日産自動車）}

R. K. Hanson (Stanford University) M. Allen (Pysical Science Institute)

Teruyuki Itoh, Nissan Research Center Akihiko Kakuho, Nissan Research Center Hashizume Yutaka, Nissan Research center Ronald.K. Hanson, Stanford University

Mark Allen, Pysical Science Institute

Key Words : Engine, Measurement, On-board, Airfuel ratio, temparature, radicals

\begin{abstract}
It's clear that the merit of visualized information in combustion chamber results in understanding the many effective physical parameters. But this system needs the modification of an engine and big power laser, very high speed camera. Additionally, it need the much time to transfer the know how for the real engine optimization and simulation models. On-board measurement system has a big merits because it easy to transfer the real engine without modification. Merits are the time and cost of these system. Several systems are commonly installed in a spark plug. This reports deals about the typical kind of method to know the gas temperature under motoring and firing condition using I.R.absorption method.
\end{abstract}

1 緒

言

1970 年代に入ってから、レーザの進歩、実用化に伴 いガソリンあるいはディーゼルエンジンの燃焼解析手 段に、様々な手法が開発され、燃焼に関わる各種物理、 化学量が高応答で計測されるようになった。一方、エン ジンの高效率、低公害性を推し進める上で、このような、 燃焼をつぶさに観測するニーズが生まれたのも、同時期 である。このような、背景とは独立に、様々なレーザが 登場したのも同時期である。各種レーザ态用の計測手法 は、そのレーザの持つ、単一波長性、高エネルギ一密度、 直進性となど、多くの長所を備えている。(1)

\section{2. 各種計測対象の背景}

ガソリンエンジンの燃焼を制御する上で、過去に $4 つ$ の大きな進化があった。この進化は、環境庁による、低 公害性一の取り込みを法制化することで、促進された面 もある。すなわち、多点点火燃焼、希薄燃焼、直噴ガソ リン燃焼、そして $\mathrm{HCCl}$ 燃焼である。

燃焼は、現在では有限な天然資源である、原油を燃料 とし、比較的分子量の低い、軽い、低沸点で高価なガソ リンと、分子量の多い、重い、高沸点の軽油、あるいは 別の言葉で表現すれば、自着火性の高い、セタン值の高 い軽油に2 分される。

これらの燃料の燃焼は、燃料の供給、空気との混合、 点火や自着火による燃焼開始、そして各種反応の後、排 出される排気ガスを生み出し、これらにみかえりの形で、 エンジンの駆動力を生み出す。

図 1 点火プラグに内蔵された、ダブルパス型光路 形状による温度測定装置の概要
燃焼索制御することは、燃焼に関わる、燃料供給、各種流 動、混合気形成、燃焼と反応、燃焼室形状などが、複雑に絡 み合っている。これらを1つ1つ可視化、定量化することが、 エンジンの熱効率向上、排気濃度の低減につながる。特に $\mathrm{HCCl}$ のような、反応依存型の燃焼コンセプトにおいては、 温度測定は重要である。(2)

\section{3. 水を用いた温度の赤外吸収法による測定}

$\mathrm{HCCl}$ のような、反応を主とした燃焼形態の場合、温度を 測定する意味は大きい。すでに、吸気ポートを 2 つ有する 4 弁エンジンにおいて、タンブル流動をベースにし、圧縮行程 の後半に、意図的に温度場の対象、非対称配置を作成し、こ の時の自己着火の様子を温度場で定性的に、よく説明してい る、当社報告がある。(3)(4)

図 1 にはプラグ先端の入射光と反射光が、水の存在空閒を 行き来することにより吸收度合いを倍にすることを意味す る。測定対象としている水は、湿度成分として大気中にある と共に、燃焼室内には既燃ガス成分として残留ガス中にある。 しかし、低濃度であるため、吸収度合いを大きくするために、

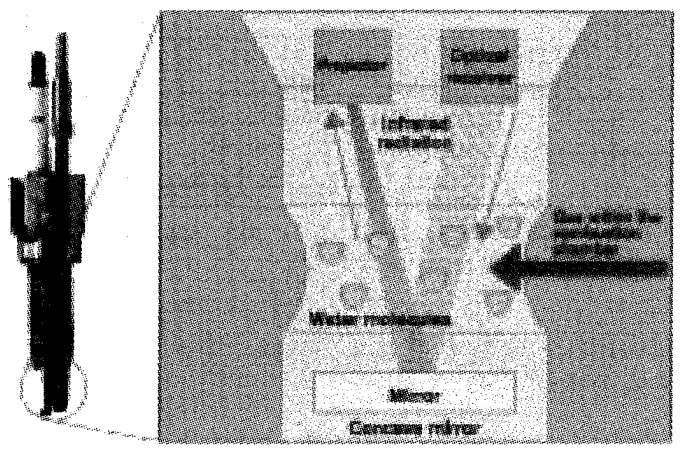


このようなダブルパス光路が必要であった。入射 光は水の存在空間を透過したのち、反射鏡により 受光用の光ファイバー端に入光する。実際には、 測定空間中での密度ゆらぎのために光路は少し 曲げられるが、全量を入射させるために受光側の ファイバー径の方が大きくしてある。

このような工夫を織り込みながら、微量な水濃 度においても精度良く測定できることを目指し た。図2は以上に述べた原理を元に、点火プラグ に内蔵したセンサープローブとセンサー部につ ながる半導体レーザ 2 本の伝送受光用光ファイ バーと水により吸収減衰してセンサーに取り迟 まれる信号処理系とを全装置図として示した。

この装置により得られた測定例を2つ示す。図 3，4 忏それぞれ、駆動、発火運転に相当する筒 内温度を示す。両データは、同一エンジンを使用 している。

測定された駆動運転時での測定結果は圧縮上 死点においてほぼ、600Kを示している。しか し、詳細に上死点近傍を見ると、上死点前に温度 のピークがあり、上死点に対して非対称形である。これ梳圧 縮による空気温度上昇が起こりつつも、さらに高温になるほ ど、シリンダ壁を通じて、放熱される熱量が増え、このため、 上死点では失われた熱量が最も多く、これを始点とする、膨 張行程では上死点に対して非対称な温度履歴になる。

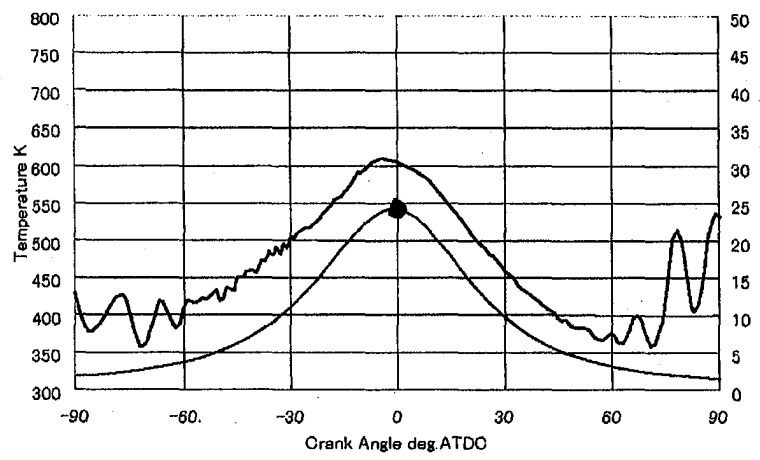

図 3 駆動運転時の圧縮膨張行程時、温度履歴

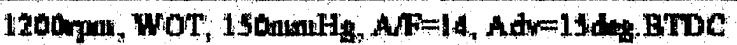

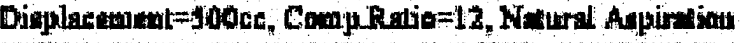

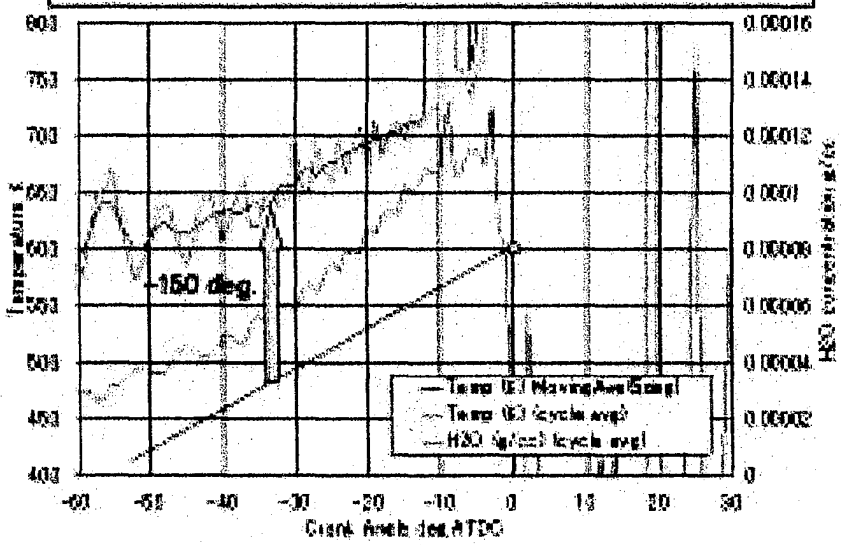

図 3 発火運転中の温度 : 温度平均值（青） 々水の密度 (赤)

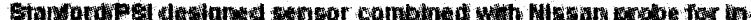

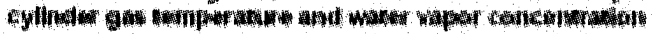

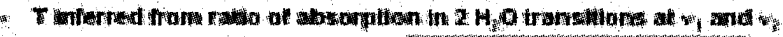

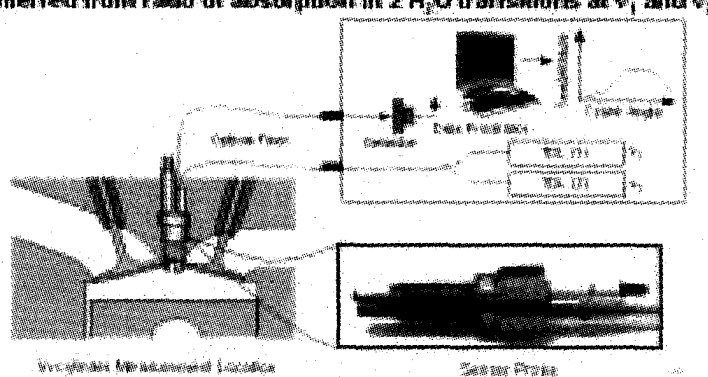

(rinthons

ISI

図 2 赤外 2 波長吸収法による水分子を利用した、燃焼室内温度 測定法の燃焼室へ適用した場合の全体構成図

つまり熱損失が上死点近傍で刻々と増えるためであり、膨張 行程はこの低下分を下敫きにするため温度は圧縮行程より、 温度がより低く低下してゆく。さらに駆動運転時の圧縮上死 点温度 $600 \mathrm{~K}$ 発火運転の図において同時期に固定し、発 火運転時の温度発火運転時の温度勾配と平行線を作ると、図 4 に示すように大よそ、約 $150 \mathrm{~K}$ の温度差が生じる。これ は残留ガスの影響であろう。(5)なお、本報告の理論につい ては国際燃焼シンポ $(2006 / 8)$ で報告済みである。(6)

$$
\text { 4. 結言 }
$$

（1）点火プラグに内蔵した赤外線透過光学系により水の濃 度から温度を求めることができた。

(2) 得られた結果は、エンジンの加工が無いので、実用エ ンジンに近い状況を捉えていると考えられる。

（3）駆動運転時にお污温度履歴は、熱伝達のため、圧縮 上死点に対して非対称形であり、膨張行程の方が低い。

(4) 発火運転時点火前では圧縮中に約 150 度ほど駆動運 転より温度が高い。これは残留ガスによるものと推定 される。

\section{5.謝辞}

本論文は、日産社内の関係部署のみならず、スタンフォー ド大学、PSI,などの多くの社外の方々の協力、指導、援助を いただいて、温度測定オンボード計測としてまとめたもので ある。ここに記して各位に深く感謝申し上げたい。

\section{参考文献}

（1）伊東、内燃機関へのレーザ計測法適用による燃焼診断 の進展、レーザ研究、The Review of Laser Engineering, Vol.33,No.3, March 2005, pp151-156

(2) Itoh,T., et.al."Qunatitative Analysis of Mixyure Preparation Processes in New Direct-Injection Spark Ignition Engines", JSME International Journal, Series B,Vol.48,No.4,2005

(3) Nagamine,M.,et.al." In-cylinder mixture temperature distribution measurement for $\mathrm{HCCl}$ combustion", F2006P050, FISITA

(4) Kakuho,A., et.al., "In-culinder Temperature Distribution Measurement and Its Application to HCCI Combustion", SAE Paper,2006-01-1202

（5）中田ら、「未燃ガス温度と混合気性状のノッキング発生 への影響」、自動車技術会論文集、Vol.25,No.3,July 1994

(6) G.B.Rieker,et.al."Rapid measurements of temperature and $\mathrm{H}_{2} \mathrm{O}$ concentration in IC engines with a spark-plug-amounted diode laser sensor", $31^{\text {st }}$ International Symposium on Combustion Aug.6-11 2006 Germany 、2F06,200 